\title{
The Important Role of Customer Information Quality on Salesperson Performance
}

\author{
$1^{\text {st }}$ Ida Bagus Nyoman Udayana ${ }^{1}, 2^{\text {nd }}$ Heru Kurniawan Tjahjono ${ }^{2}, 3^{\text {rd }}$ Nuryakin $^{3}, 4^{\text {th }}$ Elya \\ Ardyan $^{4}$ \\ ibn.udayana@yahoo.co.id ${ }^{1}$ \\ Universitas Sarjanawiyata Tamansiswa, Indonesia ${ }^{14}$. \\ Faculty of Economics Universitas Muhammadyah Yogyakarta Indonesia ${ }^{23}$
}

\begin{abstract}
Abstrac. This study examines factors influencing customer information quality and salesperson performance. Data collected were 450 salespersons in the field of small and medium enterprises. The analysis used is structural equation modeling (SEM). Then, the data were analyzed using Amos version 21 software. The results indicate that customer information quality creates a linkage between adaptive selling and salesperson performance. In addition, communication ability and trustworthiness have a significant positive effect on salesperson performance. Further discussion, limitations and direction for future research are also discussed in this study.
\end{abstract}

Keywords: Customer Information Quality, Salesperson Performance; Adaptive Selling, Communication Ability, Trustworthiness.

\section{Introduction}

Salespersons play important role in a company (Ahearnea and Gruenb and Jarvisc, 1999; Basir and Ahmad and Kitchen, 2010)[1]. Raymond and Tanner (1994) [2] explain that they can create competitive advantage, and they are also good critical market intelligent. Further, they are people who interact with potential customers (J. Kim and Kim, 2014; Lee and Dubinsky, 2017; Simintiras and Cadogan, 1996)[3], share values (Gillis and Pitt and Robson and Berthon, 1998; Naylor and Frank, 2000)[4], and connect (Douglas Amyx and Bhuian and Shows, 2016; Drollinger and Comer, 2012; Yu and Tung, 2014)[5] with customers. These salespersons are supposed to maitain the trust of the customers (Twing-Kwong and Albaum and Fullgrabe, 2013; Yu and Tung, 2014)[6]. Some important factors related to salespersons are adaptive selling (Limbu and Jayachandran and Babin and Peterson, 2016; Rakesh Singh and Gopal Das, 2013) [7] and the customer information quality. The performace should be kept well because good performance gives impact to companies. Therefore, the companies should develop and empower the salespersons based on the companies' capability (Ahearnea and Jones, 2008; Yao and chen and Cai, 2013)[8].

Information is very important for a company. Currently, there are many irrelevant and unreliable information received by managers (Gelle and Karhu, 2003)[9]. Based on the phenomenon of "garbage in-garbage out", the quantity of the customer information will give 
impact to managerial decision. The information can be useless if it is not well managed for companies's benefit (Hu and Huang and Kuse and Su and Wang, 1997)[10]. The unreliable information will give impact to wrong decision making and performance. Many companies make use of technologies to collect, save, and analyze information (Madnick and Wang and Lee and Zhu, 2009)[11]. One of them is using CRM system (Chuang and Lin, 2013). The use of the system will make companies easier to gather information fast (Chen and Popovic, 2003)[12].

The success of the performance by the employees are influenced by various factors. One of them is the ability to communicate which is regarded as an important factor determining the success of salesperson's task (Bahaa Abdul-Hafez and Al-Nady, 2016 )[13]. Besides, the capability of salesperson to build customers' trust upon their offered products. In fact, the customors' trust which is built is as a result of a long process and time (Raj Agnihotria and Krushb, 2015; Fang Yulin and Israr Qureshi and Heshan Sun and Patrick McCole and Elaine Ramsey and Lim, 2014)[14]. The capability of salespersons to adapt well during their interaction with customers will result on the good perfomance lead to the increases of selling.

Meanwhile, it is found that there is still inconsistency of the result of the research between adaptive selling and salesperson's performance. There are still contrary between the previous results. Some researches mention that the adaptive selling influences the salespersons's performance (Kidwell and McFarland and Avila, 2007; Ramendra Singh and Gopal Das, 2013); (Chirani and Matak, 2012); (Ramendra Singh and Das, 2011); (Kidwell et al., 2007; Pettijohn. and Schaefer and Burnett, 2014)[15]. On the contrary, some show that the adaptive selling has no positive impact towards the salesperson's performance (Abed and Haghighi, 2009; Binu Markose, 2011; Bolander and Satornino and Hughes and Ferris, 2015)[16]. This research investigates factors influencing customer information quality and salesperson performance.

\section{Literature Review}

\section{Adaptive Selling Behavior}

Adaptive selling behavior is one of the most important capabilities of a salesperson needs to acquire. This involves adjustment (Weitz and Sujan and Sujan, 1986)[17]. Pettijohn and Pettijohn and Keillor (2000)[18] explains that effective selling occur when salespersons are able to adapt with their customers. The salesperson should understand that every customer has different needs and beliefs (Spiro and Weitz, 1990)[19]. Salesperson must be motivated to approach the customer. Each customer has each characteristics and uniqueness that salespersons should pay attention to (Chai and Zhao and Babin, 2012)[20] in order to give positive impact on selling performance (Hughes et al., 2012). Adaptive selling allows the sellers to customize the products to fit the customer needs and preferences (Rakesh Singh and Gopal Das, 2013)[21]. Positive perceptions of customers to adaptive selling behavior will have an impact on increasing the customer's confidence (Guenzi and De Luca and Spiro, 2016)[22]. Adaptive selling behavior must also be based on a sense of empathy for customers in which salespersonsshould understand and respond emotionally to them(Limbu et al., 2016)[23].

\section{Customer Information Quality}


The quality information about customers is very important for the company. Salespersons should be able to find quality information related to their customers. Kerr (1996) explains that one of the skills in managing information overload is by being able to select the most important part of it. Quality information refers to valuable information, not its quantity, and therefore, it emphasizes the quality and nature of information (Zhou and Benton Jr., 2007)[24]. Forslund (2007) explains that the quality of information is measured by timeliness, accuracy and accessibility. Complete and comprehensive information is very helpful for sales managers to make decisions in selling. In addition, the accuracy of information such as information correctness, less errors and accuracy level also determine the quality information. Quality information has an approach to be more customer-focused (Lilrank, 2003).

\section{Trustworthiness}

Customer trust is an important thing that should be created and maintained by the company (C. H. Schwepker and Good, 2012)[25]. Sutter and Kocher (2007) explain that trustworhiness is a fundamental element of efficient interaction. Companies that are able to create trust have the potential to keep the company alive. Employee integrity and trust are urgently needed and should be maintained well. Managers who can maintain customers' integrity makes the company can easily offer its products to them(Adewale and Yusuf and Mat Ghani and Meera and Manap, 2012)[26]. Fair and honest treatment for customers can increase customer's confidence in the company. Honesty meansthat once companies give gifts for customers, it should be fair and the company must also be honest with the product sold such as its weakness so that customers can anticipate well (Cheung et al., 2013b)[27].

\section{Salespersons Performance}

Salesperson performance is very important for the company. Salesperson is one's contribution to the sales target set by the company (R. Singh and Koshy, 2010)[28].These targets should be measurable and realistic to achieve. The performance of salespersons can be based on sales quotas and comparative performance in their departments (Babakus and Cravens and Grant and Ingram and LaForge, 1996)[29]. Salespersons' performance can also be seen from the sales targets and salespersons' ability to increase market share (Behrman and Perreault, 1982; Rakesh Singh and Gopal Das, 2013)and to achieve goals (Brown and Peterson, 1994)[30]. Sujan et al. (1994) explain that the desire to be rewarded is the motivation of the salespersons in achieving its performance. The performance of the salespersons will ultimately have an impact on the company's performance. Therefore, companies should pay attention to encourage salespersons to perform better.

\section{Hypothesis}

\section{Adaptive selling and customer information quality}

Customers have different characteristics that require different approaches (Locander and Mulki and Weinberg, 2014)[31]. This is very important for salespersons in relation to customer information needs. Salespersons desperately need accurate information from customers. Accuracy and completeness of information obtained from customers can determine the quality of information. Information from customers can be obtained depending on the 
ability of the salesperson in understanding the needs and demands of the customer. Salespersons can optimize information technology in relation to customer information search (Khudri and Sultana, 2015)[32]. Through the use of information technology, there is a high efficiency and effectiveness. The use of information technology process is simple while the accuracy is high. Simple process means practical which can be carried out anywhere and anytime such as by using androidhandphone. The behaviour of an adaptive salesperson will greatly affect the quality of customer information.

\subsection{Adaptive selling can improve customer information quality.}

\section{Adaptive selling and salesperson performance}

Salespersons should understand customers well (Douglas Amyx and Sharma and Alford, 2014; Bolander et al., 2015; Fred and R., 2013)[33]. Through experiment, a salesperson can easily understand the needs and desires of the customer. It requires patience and persistence. The uniqueness of each customer requires a different approach for different customers. The skills of a salesperson are needed in carrying out the selling tasks (Piercy and Cravens and Lane, 2012)[34] The skill includes mastery of various approaches in sales so that if the approach used does not run well, then they can easily replace with another approach that is more appropriate to the situation and real condition. This is important because this action has the potential to improve the performance of salespersons.

The ability of salespersons who can adjust when interacting with customers is likely to improve selling performance (Yilmaz, 2001)[35].Salespersons who can understand well the needs and desires of customers resulting in satisfied customers. This consumer satisfaction can lead to repeat purchase and will not be easy to move to another brand. Loyal customers have an impact on increasing the company's sales volume (Xiabing and Christy and Matthew and Liang, 2015)[36]. In addition to repurchasing, as customers feel satisfied with the products, the customer will recommend to friends and relatives to buy certain products. Increased sales volume can result in company profits. Increased profit can be used to improve the strategy for market share expansion. Thus, the hypothesis that can be proposed is:

\subsection{Adaptive selling can improve salespersons performance}

\section{Communication Ability and Customer Information Quality}

The ability to communicate effectively of a salesperson is one of the key factors for obtaining quality information from customers (B. Kim and Kim, 2016; Seyoon and Jungwoo, 2014)[37]. The forms of communication can be various, among others: conversations via telephone, via electronic mail and can also communicate face to face. Communication effectiveness can be measured from customer response rates (Jun-Gi Park and Lee, 2014; Ponduri and Bala, 2014)[38]. If the customer responds well, it can be said that the communication is effective. In addition, the quality of communication can be measured by the benefits obtained through communication. The more useful the communication is, the better the response from the customer. Relevance and content in communication greatly determine customer's satisfaction (Jun - Gi Park and Lee and Lee, 2014)[39]. Customers who get relevant and quality information as required make them satisfied. The more qualified and relevant information obtained from the salespersons, the quality of relations with customers can be increased. 
Good and structured communication tends to create better relations quality with customers(Veenraj and Ashok, 2014)[40].Having good communication will lead to objective critics. This objective critic is needed for future betterment. The organisation that can pay attention to other parties tend to professionally develop.

(Bahaà Abdul-Hafez and Al-Nady, 2016; Toyese, 2014)[41]. The more the quality information obtained, the more precise the decision making process the company will make. Therefore, to gather good quality information, salespersons should have good communication skills. Hence, the proposed hyphothesis is:

\subsection{Communication Ability is able to improve Customer Information}

\section{Quality}

\section{Trustworthiness and Customer Information Quality}

Trust is an important factor in maintaining the quality of information obtained from customers (Agnihotria \& Krush, 2015; Cheung et al., 2013a; Fang Yulin et al., 2014)[42]. The salesperson's job is how to build and maintain customer trust. Customer trust is a very strategic way to maintain good relationships with customers which canmake quality of information better (Animesh et al., 2011; Tsai et al., 2010). If the customer's trust is detected, then the salesperson should have to maintain and develop the confidence through providing certainty to the customers for the product he has purchased. The form of maintaining the quality of customer information can be carried by giving warranty on the goods that have been purchased (Schwepker \& Good, 2012b; Shpëtim Çerri, 2012)[25], providing the best service and being honest with customers. In addition, high integrity will determine the success of salespersons to maintain the quality of relationships with customers.

Customer trusts to salespersons tend to increase customer openness to them (Chu \& Yuan, 2012; Fang Yulin et al., 2014)[42]. Building customer trust is a process and takes place in a relatively long time. In the process of building customer trust, this is a tough task for a salesperson. The salesperson must be honest to the customer. This honesty has the potential to increase the level of customer satisfaction (Cheung et al., 2013a; Shpëtim Çerri, 2012). Further, satisfied customers tend to be able to provide very useful quality information to a salesperson. Based on the above analysis, hypothesiscan be proposed:

\subsection{Trustworthiness can improve Customer Information Quality}

\section{Communication ability and salesperson performance}

A quality communication skill for a salesperson is one of the key success factors in meeting customer needs and demands (Abdul-Hafez \& Al-Nady, 2016; Toyese, 2014)[43]. Quality communication can increase customer's satisfaction that makes customers ultimately tend to include purchasing decisions. Interacting with customers regularly and systematically is a must for them (Kim \& Kim, 2016; Ponduri \& Bala, 2014)[3]. Through this interaction, there will be information about the products which can be delivered effectively. Further, through face-to-face approach, interaction with customers would be very helpful for them to make decisions (Park et al., 2014; Zieliński, 2013)[44]. In order to make communications run effectively, the salespersons can use telephone, electronic or email media. Through this method, itwill reduce costs, so that communication becomes more efficient and effective. The efficient communication tends to improve the performance of the salespersons. 
The role of salespersons to improve selling performance is critical (Bolander et al., 2015; Pettijohn et al., 2014)[44]. Thus, the ability of a salesperson in expanding the network and building relationships with customers as wide as possible is a very urgent and absolute and should be carried out. Broad and quality networks tend to support the performance of salespersons so that the selling performance continues to increase (Miao \& Evans, 2013; Piercy et al., 2012). A quality network of subscribers is widening if it is accompanied with the ability of salespersons to adapt when interacting with the customers (Miao \& Evans, 2013). The salesperson who can apply a good approach with customers using interesting presentations makes customers feel satisfied. Consumers who are satisfied with the product they have purchased, they will make a re-purchase (Piercy et al., 2012). With this increasing redistribution, it tends to improve the performance of salespersons.

Salespersons should acquire quality communication if they want to improve his selling performance (Chengiz Yilmaz, 2002; Parka \& Deitzb, 2006). The accuracy of the information for the customer is the key to succeed in communicating with customers. Salespersons who can respond well to customers' complaints and are able meet their needs and demand will make them satisfied (Amyx et al., 2014). Moreover, if they are supported by the ability to provide appropriate and useful information for customers. Relevant and useful information for customers has the potential to improve selling performance. The increased sales is one of the key indicators to measure the success of salespersons (Basir et al., 2010b)[44]. However, there are many indicators that can be used to determine the success of a salesperson, among others; increased market share, sales growth, increased profitability of the company, and less complaints by the customer. Therefore, the ability to communicate well has the potential to improve the performance of salespersons. Thus, the researcher proposed the following hyphothesis:

\subsection{Communication ability can increase salesperson performance}

\section{Customer Information Quality and Salesperson Performance}

Quality information from customers is very useful for the company (Setia et al., 2013). The company will find it helpful to obtain the information which can be used properly. It means that the company will easily make strategy to use (Nevo \& Wade, 2010; Ou et al., 2013; Ponduri \& Bala, 2014)[38]. In fact, salespersons customers can re-purchase. This repurchase can improve selling performance which ultimately can increase company profit. If this can be maintained, it is possible that salesperson performance will increase and it will affect the employee's welfare (Xiabing et al., 2015; Zhu Dong Hong, 2015). So that, the profit of the company can occur in a relatively long run because the profit achieved by the company due to customer's satisfaction. In addition, the honesty of information given by customers can also help the company to determine what strategy which will be used to satisfy customers. Thus, the proposed hypothesis is:

\subsection{Customer Information Quality and Salesperson Performance}

\section{Trustworthiness and Salesperson Performance}

Customer safety is a key consideration in relation to salespersons (Agnihotria \& Krushb, 2015; Chu \& Yuan, 2012; Fang Yulin et al., 2014)[42]. Customers who feel secure in the transaction will not hesitate to spend money to conduct transactions with salespersons. The job of the salesperson is to build and maintain trust from the customer. Trust can be built by 
providing the best service and always paying attention to what the customers' needs and demands (Tsai et al., 2010). Consistency between the information available to the product should be absolutely carried out by the company. We are supposed not to make customers disappointed. In addition, honesty to customers is needed in building customers' trust (Cheung et al., 2013a; Chu \& Yuan, 2012; Shpëtim Çerri, 2012). Honesty can be realized by providing precise and accurate information about the product. For example about the superiority of a product and the proper use of the product. Customer trust that can be built through consistent quality of products and satisfactory services which can affect the performance of salespersons.

The Increased market share is as one of the ways to improve selling performance (Basir et al., 2010b; Parka \& Deitzb, 2006; Piercy et al., 2012)[45]. Some expand the market share. Further, expanding customer networks is an effective way to increase market share. Through a vast network of information about the needs and demands of customers can be known more quickly and better. Communication occurs through a wide customer network which can improve the effectiveness and efficiency of communication with customers and reduce incorrect information about the products (Ahearne \& Jones, 2008; Park \& Deitzb, 2006)[8]. Broad networks can increase the intensity of communication with customers. Sales targets can be met if supported by a wide customer network (Chengiz Yilmaz, 2002). Therefore, through a wide network, the performance of salespeople can be improved.

\subsection{Trustworthiness is able to increase Salesperson Performance}

\section{Research methodology}

\section{Sample frame and data collection.}

Health Insurance Company is selected as a research object because the public awareness on health in Indonesia is very high. This can be seen from the number of insurance participants which always increases from year to year. Further, the number of hospitals also continues to increase every year and the public health service also keeps increasing.

The ability of the salespersons to explain well and correctly about the health products helps customers to make the decision to purchase the products. This ability is required to understand well the needs of customers. Thus, professional services should be provided. These can be carried out through different approaches for different customers. Adaptive approach is neeeded if the applied one does not run well. The professional salespersons can easily overcome the difficulties faced by the customer, adaptable to the conditions and circumstances of the customers and they can easily understand well customer behavior (David A et al., 2014; Subhra Chakrabarty et al., 2013). In addition, the salespersons are required to understand well about the product knowledge. Mastery of product knowledge is an important factor and determines the success of the selling (Dulger et al., 2016; Zhu Dong Hong, 2015)[46]

The data of this study were collected through questionnaires, while the unit of analysis was the salesperson of the health insurance policy in Yogyakarta, Indonesia. The object of the research is a number of insurance companies in Indonesia. Respondents were taken by purposive sampling method. Respondents fill out the questionnaires that have a minimum of 5 years work experience in selling of insurance policies. Further, the age of respondents at least 17 years old with minimum education level of senior high school. Number of respondents was 400 with $91 \%$ return rate. Data were collected from January to June 2017. Then, the data collected were tested which involve validity test, reliability, non-response bias test, logical connection test (Ferdinand, 2013). 


\subsection{Measurement}

Small sample is used for pre-test. This is carried out to test the validity of a questionnaire especially its indicator. The data test was performed with non-response bias technique, validity and reliability test. The tests are continueslyconducted until all the data meet the valid criteria and reliability. A valid and reliable questionnaire will be able to capture good and correct data. Thus, the questionnaire is feasible and reliable to collect research data. The 10point Likert scale questionnaire is used from 1 (from strongly disagree) to 10 (strongly agree) to measure all indicator variables (Imam Ghozali, 2011).

\section{Results}

\subsection{Validity and Reliability}

Questionnaires used in the research should be first tested its validity and reliability. Validity is the ability of instruments to measure what need to be measured. An indicator is said to be valid if the indicator has a loading factor value of minimum 0.60 . Then, if it has the loading factor is below 0.60, it means that that the item is not feasible to measure the variables (Imam Ghozali, 2011). The research questionnaire should be valid and must also be reliable. The quality of research data is determined by the quality of the questionnaire. The more valid and reliable a questionnaire, the higher the quality of research data (Imam Ghozali, 2011). Thus, it can be said that the quality of data analysis can be determined by the data collected during the research.

Non response bias test is conducted aiming to see whether the characteristics of respondents fillingin the answers to the questionnaire timely with those who are late fillingout different questionnaires. If it is different, it will affect the results of data analysis and it is regarded as a serious problem if response rate is low. Non-response bias test is appliedusing independent sample t-test by looking at the average of the respondent's answers in the group at the time they fill inthe questionnaires timely with those who are not. The significant difference between the population variance to the two samples can be seen in the levene`s test for equality of variance which can be seen intable 4:20.

A logical connection between the indicator variables of the two hypothesized variables should be performed. This needs to be carried out to ensure that the indicator of the independent and dependent variableswere hypothesized to have a logical causality relationship (Ferdinand, 2014). Thus, it can present logical connection of each indicator in one research variable. In addition, it is necessary to test the role of mediation variables in a research model. Sobelt test analysis (Oper, D.S. 2014) is an analysis tool to test the role of variable mediation of a variable that is the role of indirect effect between the dependent and the independent variables. This test can provide information showing the significance of the role of mediation variables to fill the gap in this study.

\section{Confirmatory factor analysis and construct validity (lihat di disertasinya)}

The model feasibility evaluation is undertaken to confirm how far the model is hypothesized according to the sample data. The model feasibility evaluation refers to some of 
the following selected criteria (Hair et al., 2010)[47]. Indicators that have loading factor below 0.50 were dropped. It is found that the statistical models are declared fit and can be accepted with the value of $\chi^{2}=77.334 ; \mathrm{df}=94 ; \mathrm{p}<.894 ; \mathrm{RMSEA}=.000 ; \mathrm{CFI}=1,000 ;$ AGFI $=.924$; $\mathrm{GFI}=.948 ; \mathrm{NFI}=.967$. While the overall $\chi 2$ is significant, the $\chi 2 / \mathrm{df}$ ratio $=.823$.

Then, the researchers assessed convergent and discriminant validity. The convergent and internal validity actually measure constructs that should theoretically be measured. This is achieved through an analysis of the reliability. Each construct has a Cronbach alpha above 0.75 (Hair and F. and Black and Babin and Anderson, 2010)[47]. The whole construct with the loading factor, the composite reliability and the avarage variance extracted (AVE) are presented in Table 1.

Table 1. Scale item with loading factor, CR and AVE

\begin{tabular}{lc}
\hline Construct & $\begin{array}{c}\text { Standardized } \\
\text { loadings }\end{array}$ \\
\hline Adaptive sellingbehavioral(Chena and Jaramillob, 2014; Maroofi and Sadegh and Sadegh and \\
Fathi, 2011) AVE = .526; Composite Reliability = .816 \\
When I feel my approach does not work, then I can easily change with other approaches \\
I use different approaches for different customers. \\
I can easily solve customer problems. \\
Customer information quality(Raj Agnihotria and Vieirab and Senrab and Gablerc, 2016; Jun \\
- Gi Park et al., 2014) AVE =.514; Composite Reliability =.834 \\
I always think about the long-term benefits for customers who buy my products. \\
I think that the time customers spend a long term investment \\
I am interested to maintain long-term sales relationships \\
I easily develop long-term relationships with customers \\
Salesperson Performance (Abed and Haghighi, 2009; J. C. H. Schwepker and Schultzb, 2015) \\
AVE = .501 Composite Reliability = .750 \\
I always generate higher levels of sales, when compared with my colleagues \\
I have always exceeded the sales targets set by the company. \\
I have always been able to increase company profit \\
Trustworthiness(Pousa and Mathieu, 2014), AVE=.561; Composite Reliability = .793 \\
I emphasize the significance for consumer satisfaction \\
I emphasize the significance of customer needs \\
I am a good listener for the customer \\
Communication ability (Dulger and Alpay and Yilmaz and Bodur, 2016; Hassan and Qureshi \\
and Hasnain and Sharif and Hassan, 2013) AVE=.629; Composite Reliability = .829 \\
The information provided by him/her was very useful for my work \\
I was very satisfied with the content of the information provided him/her \\
The information provided by him/her was highly relevant to may work \\
\hline
\end{tabular}

\subsection{Parameter Value Estimation}

Figure 2 shows that adaptive selling has a significant positive effect on salesperson performance through customer information quality. Furthermore, the adaptive selling, communication ability and the trustworthiness have a significant positive effect on the customer networking quality and the salesperson performance. Thus, the role of the variable of the customer information quality is a key factor to improve salesperson performance. 


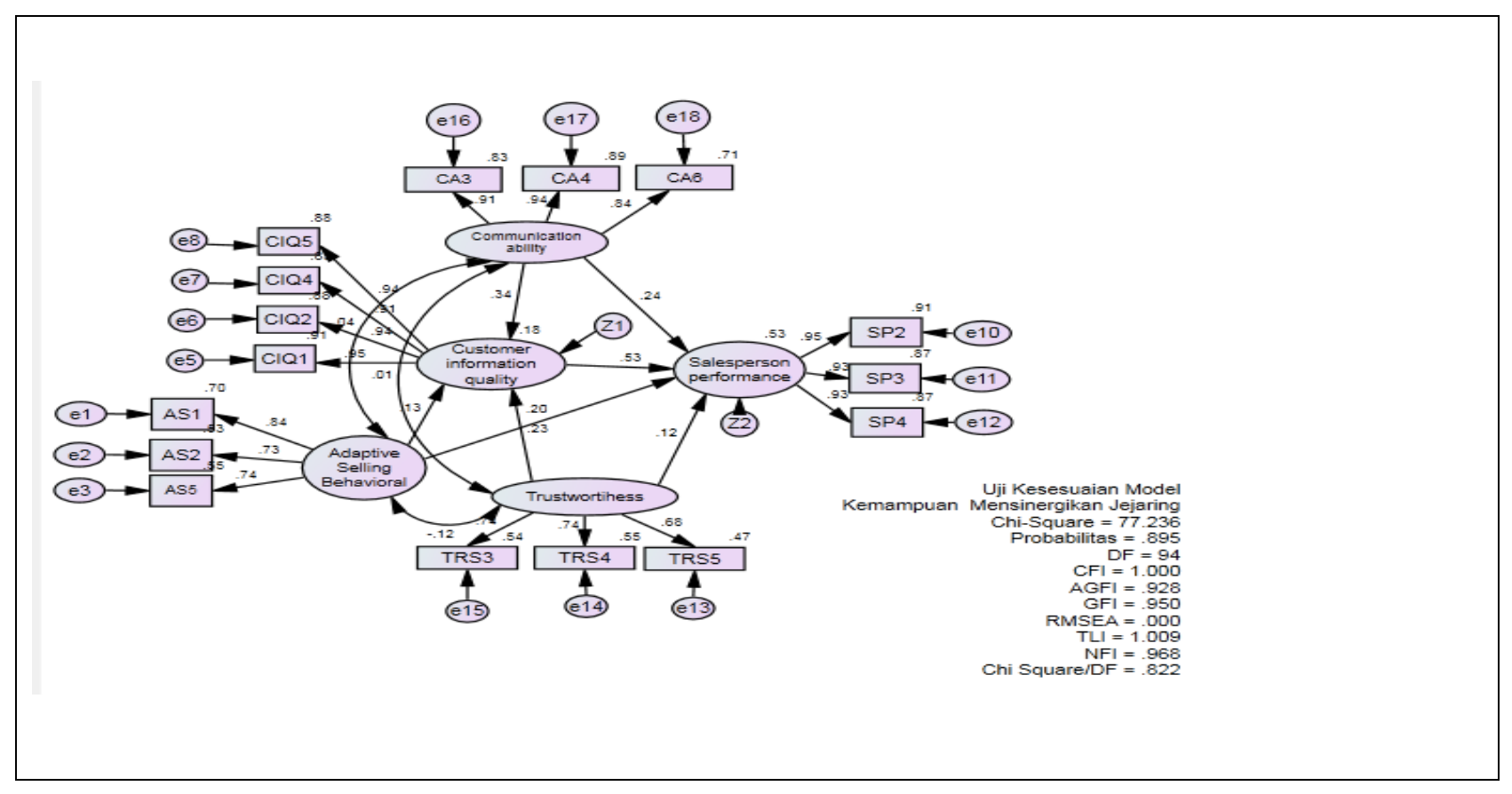

Figure 1 Structural Equation Model Analysis

\section{Hypothesis testing}

The hypothesis testing can be seen from the results of the standardized coefficient regression. The estimation results are presented in table 2:

Table 2. Standardized Regression Weights: (Group number 1 - Default mode)

\begin{tabular}{ccccccc}
\hline & Path & & & $\beta$ & Sig & Comment \\
\hline H1 & Customer information quality & $\leftarrow$ & Adaptive Selling behavioral & .122 & .133 & Rejected \\
H2 & Salesperson Performance & $\leftarrow$ & Adaptive Sellingbehavioral & .201 & .002 & accepted \\
H3 & Customer information quality & $\leftarrow$ & Communication ability & .328 & $* * *$ & accepted \\
H4 & Customer information quality & $\leftarrow$ & Trustworthiness & .219 & .011 & accepted \\
H5 & Salesperson Performance & $\leftarrow$ & Communication ability & .230 & $* * *$ & accepted \\
\hline
\end{tabular}




\begin{tabular}{lcccccc}
\hline H6 & Salesperson Performance & $\leftarrow$ & Customer information quality & .533 & $* * *$ & accepted \\
H7 & Salesperson Performance & $\leftarrow$ & Trustworthiness & .131 & .061 & Rejected \\
\hline \multicolumn{3}{c}{$N=259 ; * p<.05 ; * * p<.01 ; * * * p<.001}$.
\end{tabular}

The adaptive selling has a significant positive effect on the customer information quality with the standardized coefficient of .182 and the probability value is .011 (Hypothesis-1). Meanwhile, the adaptive selling does not have an effect on the salesperson performance with the standardized coefficient of .109 and the probability value of .091 (Hypothesis-2). The customer orientation has a significant positive effect on the selling relationship quality with the standardized coefficient of .318 and the probability value is .000 (Hypothesis-3). The learning orientation has a significant positive effect on the selling relationship quality with the standardized coefficient of .296 and the probability value is .000 (Hypothesis-4). The customer orientation has a significant positive effect on the salesperson performance with the standardized coefficient of .227 and the probability value is .000 (Hypothesis-5). The selling relationship quality has a positive significant effect on the salesperson performance with the standardized coefficient of .531 and the probability value is .008 (Hypothesis-6). The learning orientation has a significant positive effect on the salesperson performance with the standardized coefficient of .187 and the probability value is .008 (Hypothesis-7).

\section{Testing a mediating role: customer information quality}

Testing for the important role of customer information quality is considered as a new concept to overcome the adaptive selling gap with salesperson performance. The important role of this new concept can be carried out using Sobel Test calculations. Sobel Test is used to assess the significance of indirect effects or the effect of mediation in structural equation model (Sobel, 1982). The result of the calculation on line is available at http://www.danielsoper.com in which its result is presented in the attachment.

Calculation Sobel test is used to test the significance of moderation variables as presented in Figure4-10explaining that customer information quality plays a significant role as a mediator to bridge the gap between adaptive selling with salespersons performance. Its evident is at the first track test Sobel value which is 2.661 with a probability value (two sides) is equal to 0.007 .Then, the second line is 2.561 with a probability value (two sides) is equal to 0.006 (see appendix), where this value is below 0.05 . Next, the third line is 2.44 with a probability value (two sides) which is equal to 0.007 . It means that the result of the significance test of the mediation variable gives an indication of how important the role of customer information quality variable is as a mediator to bridge the research gap between adaptive selling with salesperson performance.

\section{Discussion}


Adaptive selling behavioral has no effect on customer information quality with beta value of 0.122 andits significance is 1.33 . This can happen due to by the lack of qualified salespeople in adapting the approach during the interaction with customers. Therefore, the ability of salespersons needs to be improved. It means that the salespersons can be more flexible using the approach when interacting with the customers. This is very important because each customer has different characteristics. These differences require different approaches. In addition, presentation materials must also be qualified and new. The quality of the product knowledge delivery is very decisive to the customer's interest whether they prefer to buy or not. The clearer the information received by the customer, the more easily understood by the customer. The costumers who already understand the clarity of the information received, the easier it is for him to make decisions. In line with the research conducted by Chena and Jaramillob (2014)[48] who found that adaptive selling has no effect on customer information quality. Furthermore, the researcher states that the salesperson who can adapt well when interacting with the customer does not necessarily get the information in accordance with the expected. Thus, there are still many factors that need to be considered in order to obtain information of the customers. As a research conducted by Singh and Das (2013b)[21], it is found that salespersons who can adapt when interacting with customers have a significant positive effect on customer information quality. Salespersons are supposed to be able to easily overcome the customers' difficultyby providing quality information.

Communication ability affects customer information quality. Its beta value is 0.201 , and its significance value is 0.002 . The salesperson's communication skills are good enough and reliable. But it still needs to be improved. The ability of salespersons to provide quality information to customers is very important. Then, through high quality information on information obtained by the customer is very helpful for customers in making decisions. In addition, relevant information presented by salespersons must also be able to meet the needs and expectation of the customers. If the information submitted is not relevant, then the customer will feel disappointed. The customers receiving relevant information can be used to make more informed purchasing decisions. Therefore, the information relevant to customer needs is very seminal for the customers to make purchasing decisions. In line with the research conducted by Fernando et al. (2016), it is found that quality information, relevant information and customer-friendly information had a significant positive effect on customer purchasing decisions.

Customer information quality is a variable that can overcome the research gap between adaptive selling behavioral and salesperson performance. Adaptive selling behavioral variable affects salesperson performance through customer information quality. Hence, the adaptive selling behavioral can only affect salesperson performance if there is customer information quality. In this case, the role of the customer information quality variable is very meaningful to be able to improve the salesperson performance. It means that salespersons who can adapt during the interaction with the customers are characterized by, among others: using a different approach for different customers, adaptive to any changing needed when once certain approach do not run well, and they can easily understand the customers and can overcome customers' difficulties, and the salesperson performance will not necessarily improve without going through customer information quality.

Customer information quality is the variable that gives the largest contribution among other antecedent variable such as communication ability variable, trustworthiness and adaptive selling behavioral, in relation to the increase of salesperson performance. The role of customer information quality is very important. Increasing customer information quality increases salesperson performance. Even adaptive selling behavior does not have a significant impact on 
salesperson performance if it is not through customer information quality. Therefore, it is expected that salespeople must place customer information quality as the main variable to be able to improve salesperson performance.

\section{Conclusion}

Customer information quality is influenced by communication ability, trustworthiness and adaptive selling behavioral. Further, salespersons can develop better relationships with customers to get quality information. Good customer relation is characterized by building good relationships, developing long-term mutual benefits and taking into account of the customer needs and desiresconsidered as a long-term investment. Customers can provide quality information to the salesperson so that the salesperson can also provide quality information to the customer. Quality and relevant information helps customers to make purchasing decisions easier. Salespersons who are able to adapt when interacting with the customers make it easier during the selling to get quality information from customers. In addition, the ability of salespeople to understand the needs and desires of customers is crucial for the success in obtaining the quality information from customers.

Salesperson performance can be improved because it is influenced by customer information quality, communication ability, trustworthiness, and adaptive selling behavioral. Further, the increase of the customer confidence will improve the performance of the salespeople. The satisfied customers of the salesperson's service lead to re-purchase the products. It is because the consumers feel satisfied due to their needs and desires can be met. To be able to understand the needs and desires of the customer, the salesperson must be good and sincere listeners for the customer. A good listener can give comments as needed and can understand the customer's feeling and provide solutions to the problems faced by the customer. If this can be carried out well by the salesperson, then the volume of the selling may increase. Increased sales mean increased profits. Therefore, the profits which are obtained by the company and the expansion of the market can be started in which it proves that salesperson's performance is increasingly high.

\section{Implication Managerial}

The salespersons can improve their quality through joining trainings and reading articles relevant to selling, consumers' taste which changes dynamically. Besides, salespersons need to improve new strategy in to sell the products for example by optimizing emotional bound strategy to improve their performance. Further, they also need to pay attention on the customer's service appropriately and timely.

\section{Limitation and Future Research}

The limitation of this study is the research area. From the scope of research, the research should be conducted in the whole island of Java so that the samples would be better. Sample adequacy determines the accuracy of research results. From the research pattern, the research pattern should be supported by longitudinal research. This study can complement the results of the cross section study. Using longitudinal research aims to gather more accurate data because the time is enough to dig the data so that the results can be more accurate. 
Then, it is suggested that the future research sample intake should be carried out throughout Java Island. Thus, the data will be obtained more representatives and the result would be more in-depth and better. In addition, it needs to do a longitudinal research so that more complete information can be gathered. Further, this research is considered new because it is from the perspective of salespersons so that it is necessary to do dyadic research to get more comprehensive research results.

\section{Refrence}

[1] et al Ahearnea, M., "If looks could sell: Moderation and mediation of the attractiveness effect on salesperson performance," Int. J. Res. Mark., vol. 16(4), no. 269-284, 1999.

[2] J. F. Raymond, M. A., and Tanner, "The role and importance of salesperson in creating a competitive advantage," J. Mark. Theory Pract., vol. 2(3), p. 126-138., 1994.

[3] J.-E. (2014) Kim, J., and Kim, "Effects of managers' communication and satisfaction on their perceived importance of value chain sustainability. Int. J. of Services and Operations Management," vol. 25(1), pp. 21-47, 2016.

[4] K. E. Naylor, G., and Frank, "he impact of retail sales force responsiveness on consumers' perceptions of value,” J. Serv. Mark., pp. 4310-322, 2000.

[5] L. B. Drollinger, T., and Comer, "Salesperson's listening ability as an antecedent to relationship selling.," J. Bus. Ind. Mark., vol. 28(1), pp. 50-59, 2012.

[6] F.-C. Yu, T.-W., and Tung, "Antecedents and consequences of insurer-salesperson relationships,” Mark. Intell. Plan., vol. 32(4), pp. 436-454, 2014.

[7] G. Singh, R., and Das, "The impact of job satisfaction, adaptive selling behaviors and customer orientation on salesperson's performance xploring the moderating role of selling experience.," J. Bus. Ind. Mark., vol. 28(7), p. 554-564., 2013.

[8] E. Ahearnea, M., and Jones, "If looks could sell: Moderation and mediation of the attractiveness effect on salesperson performance," Int. J. Res. Mark., vol. 16(4), pp. 671-685, 1999.

[9] K. Gelle, E., and Karhu, "Information quality for strategic technology planning," Ind. Manag. Data Syst., vol. 103(8), pp. 633-643, 2003.

[10] et al Hu, J., "Customer information quality and knowledge management: A case study using knowledge cockpit,” J. Knowl. Manag., vol. 1(3), pp. 225-236, 1997.

[11] et al. Madnick, S., "Overview and framework for data and information quality research,” ACM J. Data Inf. Qual., vol. 1(1), p. 1-22., 2009.

[12] K. Chen, I. J., and Popovic, "Understanding customer relationship management (CRM) people, process and technology,” Bus. Process Manag. J., vol. 9(5), pp. 672688, 2003.

[13] A. Abdul-Hafez, B., and Al-Nady, "The role of time, communication, and cost management on project management success: an empirical study on sample of construction projects customers in Makkah City, Kingdom of Saudi Arabia," Int. J. Serv. Oper. Manag., vol. Vol. 23 (N, pp. 76-113, 2016.

[14] M. T. Agnihotria, R., and Krushb, "Salesperson empathy, ethical behaviors, and sales performance: the moderating role of trust in one's manager," J. Pers. Sell. Sales Manag., vol. 35(2), pp. 164-174, 2015.

[15] et al. Kidwell, B., "Perceiving Emotion In The Buyer-Seller Interchange: The 
Moderated Impact On Performance,” J. Pers. Sell. Sales Manag., vol. Vol. 32 (N, pp. 119-132, 2007.

[16] M. Abed , G. M., and Haghighi, "The effect of selling strategies on sales performance,” Bus. Strateg. Ser., vol. Vol. 10 No, pp. 266-228, 2009.

[17] et al Weitz, B. A., "Knowledge, motivation, and adaptive behavior: A framework for improving selling effectiveness," J. Mark., vol. 50(4), pp. 174-191, 1986.

[18] et al Pettijohn., C. E., "Salesperson Performance The Role of Role Ambiguity, Autonomy and self-Efficacy," cademy Mark. Stud. J., vol. 99-18(1), pp. 99-111, 2014.

[19] B. A. Spiro, R. L., and Weitz, "Adaptive selling: Conceptualization, measurement, and nomological validity,” J. Mark. Res., vol. 27(1), p. 61-69., 1990.

[20] et al. Chai, J., "An empirical study on the impact of two types of goal orientation and salesperson perceived obsolescence on adaptive selling.," J. Pers. Sell. Sales Manag., vol. 32(2), p. 261-273., 2012.

[21] G. Singh, R., and Das, "The impact of job satisfaction, adaptive selling behaviors and customer orientation on salesperson's performance: exploring the moderating role of selling experience.," J. Bus. Ind. Mark., vol. Vol. 28 (, pp. 554-564, 2013.

[22] et al. Guenzi, P., "The combined effect of customer perceptions about a salesperson's adaptive selling and selling orientation on customer trust in the salesperson: a contingency perspective,” J. Bus. Ind. Mark., vol. 31(4), pp. 553-564, 2016.

[23] et al. Limbu, Y. B., "Empathy, nonverbal immediacy, and salesperson performance: the mediating role of adaptive selling behavior," J. Bus. Ind. Mark., vol. 31(5), pp. 654-667, 2016.

[24] W. C. Zhou, H., and Benton Jr., "Supply chain practice and information sharing," J. Oper. Manag., vol. 25(6), p. 1348-1365., 2007.

[25] D. J. Schwepker, C. H., and Good, "Sales Quotas: Unintended Consequences on Trust in Organization, Customer-Oriented Selling, and Sales Performance," J. Mark. Theory Pract., vol. 20(4), p. 437-452., 2012.

[26] et al Adewale, A. A., "The Role of Institusional Trust in the Adoption of Gold Dinar in Klantan: An Empirical Analysis,” J. Appl. Sci., vol. 12(20), p. 2148-2155., 2012.

[27] H.-N. Chuang, S.-H., and Lin, "he roles of infrastructure capability and customer orientation in enhancing customer-information quality in CRM systems: Empirical evidence from Taiwan,” Int. J. Inf. Manage., vol. 33(2), pp. 271-281, 2013.

[28] A. Singh, R., and Koshy, "Determinants of B2B salespersons' performance and effectiveness: A review and synthesis of literature,” J. Bus. Ind. Mark., vol. 25(7), pp. 535-546, 2010.

[29] et al. Babakus, E., "Investigating the relationships among sales, management control, sales territory design, salesperson performance, and sales organization effectiveness," Int. J. Res. Mark., vol. 13(4), p. 345-363., 1996.

[30] R. A. Brown, S. P., and Peterson, "The effect of effort on sales performance and job satisfaction,” J. Mark., vol. 58, pp. 70-80, 1994.

[31] et al. Locander, D. A., "How do salespeople make decisions? The role of emotions and deliberation on adaptive selling, and the moderating role of intuition," Psychol. Mark., vol. 31(6), pp. 387-403, 2014.

[32] S. Khudri, M. M., and Sultana, "Determinants of service quality and impact of service quality and consumer characteristics on channel selection.," Br. Food Journal, vol. 117(8), p. 2078-2097., 2015.

[33] E. K. Fred, M. C., and R., "The interactive effects of sales control systems on 
salesperson performance: a job demands-resources perspective. J. of the Acad,” Mark. Sci., vol. 41, p. 73-90., 2013.

[34] et al. Piercy, N. F., "ales Manager Behavior-Based Control and Salesperson Performance: The effects of Manager Control Competencies and Organizational Citizenship Behavior.," J. Mark. Theory Pract., vol. Vol. 20(No, p. 7-22., 2012.

[35] C. Yilmaz, "Salesperson Performance and Job Attitudes Revisited An Extended MOdel and Effects of Potential Moderators," Eouropean J. Mark., vol. 36, p. 13891414., 2001.

[36] et al Xiabing, Z., "Building brand loyalty through user engagement in online brand communities in social networking sites.," Inf. Technol. People, vol. Vol. 28 (N, p. 90106., 2015.

[37] L. Seyoon, L., and Jungwoo, "Communication effectiveness on IT service relationship quality," Ind. Manag. Data Syst., vol. Vol. 114(N, p. 321-336., 2014.

[38] E. S. Ponduri, S. B., and Bala, "Role of Information Technology in Effective Implementation of Customer Relationship Management," J. Mark. Commun., vol. 9(3), pp. 50-55, 2014.

[39] S. L. a. J. Park, J.-G., and Lee, "Communication effectiveness on IT service relationship quality.," Ind. Manag. Data Syst., vol. 114(2), pp. 321-336, 2014.

[40] J. Veenraj, P., and Ashok, "Mpact Of Shopper Marketing On Purchase Decisions Of Information Technology Devices For Personal Use By Indian Consumers.," J. Theor. Appl. Inf. Technol., p. 64(3)., 2014.

[41] A. Y. Toyese, "Customer relationship management and customer loyalty in Nigerian telecommunication industry.," J. Bus. Retail Manag. Res., vol. 8(2), p. 1-7., 2014.

[42] et al. Fang Yulin, "rust, Satisfaction, And Online Repurchase Intention: The Moderating Role Of Perceived Effectiveness Of E-Commerce Institutional Mechanisms," MIS Q., vol. 38(2), pp. 407-427, 2014.

[43] A. Abdul-Hafez, B., and Al-Nady, "The role of time, communication, and cost management on project management success: an empirical study on sample of construction projects customers in Makkah City, Kingdom of SaudiArabia," Int. J. Serv. Oper. Manag., vol. Vol. 23, p. 1, 2016.

[44] et al. Park, J.-G., "Communication effectiveness on IT service relationship quality," Ind. Manag. Data Syst., vol. Vol. 114(N, p. 321-336., 2014.

[45] et al. Basir, M. S., "The relationship between sales skills and salesperson performance: An empirical study in the Malaysia Telecommunications Company.," Int. J. Manag. Mark. Res., vol. 3(1), pp. 51-73, 2010.

[46] et al. Dulger, M., "How does learning orientation generate product innovativeness and superior firm performance?,” Int. J. Bus. Econ. Dev., vol. Vol. 4(No., p. 68-77., 2016.

[47] et al. Hair, J., Multivariate Data Analysis, Seventh Ed. New Jersey Pearson Prentice Hall. Hartwick, J. , 2010.

[48] F. Chena, C.-C., and Jaramillob, "The double-edged effects of emotional intelligence on the adaptive selling-salesperson-owned loyalty relationship," double-edged Eff. Emot. Intell. Adapt. selling-salesperson-owned Loyal. Relatsh., vol. No. 34(No., pp. 33-50, 2014.

1. Abdul-Hafez, B., and Al-Nady, A. (2016). The role of time, communication, and cost management on project management success: an empirical study on sample of 
construction projects customers in Makkah City, Kingdom of Saudi Arabia. Int. J. Services and Operations Management, Vol. 23 (No. 1), pp. 76 - 113.

2. Abdul-Hafez, B., and Al-Nady, A. (2016 ). The role of time, communication, and cost management on project management success: an empirical study on sample of construction projects customers in Makkah City, Kingdom of SaudiArabia. Int. J. Services and Operations Management, Vol. 23 (No. 1 ).

3. Abed , G. M., and Haghighi, M. (2009). The effect of selling strategies on sales performance. Business Strategy Series Vol. 10, No. 5, , pp. 266 - 228.

4. Adewale, A. A., et al. (2012). The Role of Institusional Trust in the Adoption of Gold Dinar in Klantan: An Empirical Analysis. Journal of Applied Science, 12(20), 21482155.

5. Agnihotria, R., and Krushb, M. T. (2015). Salesperson empathy, ethical behaviors, and sales performance: the moderating role of trust in one's manager. Journal of Personal Selling \& Sales Management, 35(2), 164 - 174.

6. Agnihotria, R., et al. (2016). Examining the impact of salesperson interpersonal mentalizing skills on performance: the role of attachment anxiety and subjective happiness. Journal of Personal Selling \& Sales Management, Vol. 36(No. 2), pp. 174 $-189$

7. Ahearnea, M., et al. (1999). If looks could sell: Moderation and mediation of the attractiveness effect on salesperson performance. International Journal of Research in Marketing, 16(4), 269-284.

8. Ahearnea, M., and Jones, E. (2008). High touch the rough high tech: The impact of salesperson technology usage on sales performance via mediating mechanisms. Management Science, 54(4), 671-685.

9. Amyx, D., et al. (2016). Customer-salespeople relationship: Influence of salespeople entrepreneurial behaviours. Marketing Intelligence \& Planning, 34(5), 586-604.

10. Amyx, D., et al. (2014). The Influence Of Role Ambiguity And Goal Acceptance On Salesperson Performance And Commitment. Marketing Management Journal,.

11. Babakus, E., et al. (1996). Investigating the relationships among sales, management control, sales territory design, salesperson performance, and sales organization effectiveness. international Journal of Research in Marketing, 13(4), 345-363.

12. Basir, M. S., et al. (2010). The relationship between sales skills and salesperson performance: An empirical study in the Malaysia Telecommunications Company. International Journal of Management And Marketing Research, 3(1), 51-73.

13. Behrman, D. N., and Perreault, W. D. (1982). Measuring the performance of industrial salespersons. Journal of Business Research, 10(3), 355-370.

14. Binu Markose. (2011). Influence of Moderators in the Relationship of Supervisory Feedback with Goal Orientation of Salespeople - An Empirical Study. IJBIT, 4.

15. Bolander, W., et al. (2015). Social Networks Within Sales Organizations: Their Development and Importance for Salesperson Performance. Journal of Marketing, Vol. 79 pp. 1 - 16

16. Brown, S. P., and Peterson, R. A. (1994). The effect of effort on sales performance and job satisfaction. Journal of Marketing, 58, 70-80.

17. Chai, J., et al. (2012). An empirical study on the impact of two types of goal orientation and salesperson perceived obsolescence on adaptive selling. Journal of Personal Selling and Sales Management, 32(2), 261-273. 
18. Chen, I. J., and Popovic, K. (2003). Understanding customer relationship management $(\mathrm{CRM})$ people, process and technology. Business Process Management Journal, 9(5), 672-688.

19. Chena, C.-C., and Jaramillob, F. (2014). The double-edged effects of emotional intelligence on the adaptive selling-salesperson-owned loyalty relationship. Journal of Personal Selling \& Sales Management, No. 34(No. 1), pp. 33 - 50.

20. Chirani, E. P. D., and Matak, S. A. (2012). Sales effectivenes from behavior approaches. . journal homepage, 2(1), 4-12.

21. Chuang, S.-H., and Lin, H.-N. (2013). The roles of infrastructure capability and customer orientation in enhancing customer-information quality in CRM systems: Empirical evidence from Taiwan. International Journal of Information Management, 33(2), 271-281.

22. Drollinger, T., and Comer, L. B. (2012). Salesperson's listening ability as an antecedent to relationship selling. Journal of Business \& Industrial Marketing, 28(1), 50-59.

23. Dulger, M., et al. (2016). How does learning orientation generate product innovativeness and superior firm performance? International Journal of Business and Economic Development., Vol. 4(No. 2), pp. 68 - 77.

24. Fang Yulin, et al. (2014). Trust, Satisfaction, And Online Repurchase Intention: The Moderating Role Of Perceived Effectiveness Of E-Commerce Institutional Mechanisms. MIS Quarterly 38(2), 407 - 427.

25. Fred, M. C., and R., E. K. (2013). The interactive effects of sales control systems on salesperson performance: a job demands-resources perspective. J. of the Acad. Mark. Sci. , 41, 73 - 90.

26. Gelle, E., and Karhu, K. (2003). Information quality for strategic technology planning. Industrial Management \& Data Systems, 103(8), 633-643.

27. Gillis, C., et al. (1998). Communication in the salesperson/customer dyad: an empirical investigation. Marketing Intelligence \& Planning, 16(2), 100-106.

28. Guenzi, P., et al. (2016). The combined effect of customer perceptions about a salesperson's adaptive selling and selling orientation on customer trust in the salesperson: a contingency perspective. Journal of Business \& Industrial Marketing, 31(4), 553-564.

29. Hair, J., et al. (2010). Multivariate Data Analysis: New Jersey Pearson Prentice Hall. Hartwick, J., seventh Edition.

30. Hassan, M. U., et al. (2013). Market Orientation, Learning Orientation And Organizational Performance: Evidence From Banking Industry Of Pakistan. Science .Internastional Journal, Vol. 25 (No. 4 ), pp. 945-956

31. $\mathrm{Hu}, \mathrm{J}$., et al. (1997). Customer information quality and knowledge management: A case study using knowledge cockpit. Journal of Knowledge Management, 1(3), 225236.

32. Khudri, M. M., and Sultana, S. (2015). Determinants of service quality and impact of service quality and consumer characteristics on channel selection. British Food Journal, 117(8), 2078-2097.

33. Kidwell, B., et al. (2007). Perceiving Emotion In The Buyer-Seller Interchange: The Moderated Impact On Performance. Journal of Personal Selling \& Sales Management, Vol. 32(No. 2), pp. 119 - 132. 
34. Kim, B., and Kim, S. (2016). Effects of managers' communication and satisfaction on their perceived importance of value chain sustainability. Int. J. of Services and Operations Management, 25(1), 21 - 47.

35. Kim, J., and Kim, J.-E. (2014). Making customer engagement fun: Customersalesperson interaction in luxury fashion retailing. Journal of Fashion Marketing and Management, 18(2), 133-144.

36. Lee, Y. J., and Dubinsky, A. J. (2017). Consumers' desire to interact with a salesperson during e-shopping: development of a scale. International Journal of Retail \& Distribution Management, 45(1), 20-39.

37. Limbu, Y. B., et al. (2016). Empathy, nonverbal immediacy, and salesperson performance: the mediating role of adaptive selling behavior. Journal of Business \& Industrial Marketing, 31(5), 654-667.

38. Locander, D. A., et al. (2014). How do salespeople make decisions? The role of emotions and deliberation on adaptive selling, and the moderating role of intuition. Psychology \& Marketing, 31(6), 387-403.

39. Madnick, S., et al. (2009). Overview and framework for data and information quality research. ACM Journal of Data and Information Quality, 1(1), 1-22.

40. Maroofi, F., et al. (2011). Adaptive Selling Behavior In Iran Automobile Sales Representatives. International Journal Of Academic Research, Vol. 3.

41. Naylor, G., and Frank, K. E. (2000). The impact of retail sales force responsiveness on consumers' perceptions of value. Journal of Service Marketing, 14(4310-322).

42. Park, J.-G., et al. (2014). Communication effectiveness on IT service relationship quality. Industrial Management \& Data Systems, Vol. 114(No. 2), pp. 321-336.

43. Park, J.-G., and Lee, S. L. a. J. (2014). Communication effectiveness on IT service relationship quality. Industrial Management \& Data Systems, 114(2), 321 - 336.

44. Pettijohn, C. E., et al. (2000). Adaptive selling and sales performance: an empirical examination. Journal of Applied Business Research, 16(1), 91-111.

45. Pettijohn., C. E., et al. (2014). Salesperson Performance The Role of Role Ambiguity, Autonomy and self-Efficacy. Academy of Marketing Studies Journal99 - 18(1), 99 111.

46. Piercy, N. F., et al. (2012). Sales Manager Behavior-Based Control and Salesperson Performance: The effects of Manager Control Competencies and Organizational Citizenship Behavior. Journal of Marketing Theory and Practice, Vol. 20(No. 1), pp. $7-22$.

47. Ponduri, S. B., and Bala, E. S. (2014). Role of Information Technology in Effective Implementation of Customer Relationship Management. Journal of Marketing \& Communication, 9(3), 50 - 55.

48. Pousa, C., and Mathieu, A. (2014). Boosting customer orientation through coaching: a Canadian study. International Journal of Bank, Vol. 32 ( No. 1 ), pp. 60-81

49. Raymond, M. A., and Tanner, J. F. (1994). The role and importance of salesperson in creating a competitive advantage. Journal of Marketing Theory and Practice, 2(3), 126-138.

50. Schwepker, C. H., and Good, D. J. (2012). Sales Quotas: Unintended Consequences on Trust in Organization, Customer-Oriented Selling, and Sales Performance. Journal of Marketing Theory and Practice, 20(4), 437-452.

51. Schwepker, J. C. H., and Schultzb, R. J. (2015). Influence of the ethical servant leader and ethical climate on customer value enhancing sales performance. Journal of Personal Selling \& Sales Management, Vol. 35(No. 2), pp. 93 - 107. 
52. Seyoon, L., and Jungwoo, L. (2014). Communication effectiveness on IT service relationship quality. Industrial Management \& Data Systems, Vol. 114(No. 2), pp. $321-336$.

53. Simintiras, A. C., and Cadogan, J. W. (1996). Behaviourism in the study of salesperson-customer interactions. Management Decision, 34(6), 57-64.

54. Singh, R., and Das, G. (2011). The Moderating role of selling experience on the relationship between job satisfaction, adaptive selling behaviors, customer intention, adn salesperson`s performance. the proceding of the ANZMAC, 376.

55. Singh, R., and Das, G. (2013). The impact of job satisfaction, adaptive selling behaviors and customer orientation on salesperson's performance: exploring the moderating role of selling experience. Journal of Business \& Industrial Marketing, Vol. 28 ( No. 7 ), pp. 554-564

56. Singh, R., and Das, G. (2013). The impact of job satisfaction, adaptive selling behaviors and customer orientation on salesperson's performance: Exploring the moderating role of selling experience. Journal of Business \& Industrial Marketing, 28(7), 554-564.

57. Singh, R., and Koshy, A. (2010). Determinants of B2B salespersons' performance and effectiveness: A review and synthesis of literature. Journal of Business and Industrial Marketing, 25(7), 535-546.

58. Spiro, R. L., and Weitz, B. A. (1990). Adaptive selling: Conceptualization, measurement, and nomological validity. Journal of Marketing Research, 27(1), 6169.

59. Toyese, A. Y. (2014). Customer relationship management and customer loyalty in Nigerian telecommunication industry. Journal of Business and Retail Management Research (JBRMR) 8(2), 1 - 7.

60. Twing-Kwong, S., et al. (2013). Trust in customer-salesperson relationship in China's retail sector. International Journal of Retail \& Distribution Management, 41(3), 226248.

61. Veenraj, P., and Ashok, J. (2014). Mpact Of Shopper Marketing On Purchase Decisions Of Information Technology Devices For Personal Use By Indian Consumers. Journal of Theoretical and Applied Information Technology, 64(3).

62. Weitz, B. A., et al. (1986). Knowledge, motivation, and adaptive behavior: A framework for improving selling effectiveness. Journal of Marketing, 50(4), 174-191.

63. Xiabing, Z., et al. (2015). Building brand loyalty through user engagement in online brand communities in social networking sites. Information Technology \& People, Vol. 28 (No. 1), pp. 90 - 106.

64. Yao, Q., et al. (2013). How internal marketing can cultivate psychological empowerment and enhance employee performance. Social Behavior and Personality: an International Journal, 41(4), 529-538.

65. Yilmaz, C. (2001). Salesperson Performance and Job Attitudes Revisited An Extended MOdel and Effects of Potential Moderators. Eouropean Journal of Marketing, 36, 1389-1414.

66. Yu, T.-W., and Tung, F.-C. (2014). Antecedents and consequences of insurersalesperson relationships. Marketing Intelligence \& Planning, 32(4), 436-454.

67. Zhou, H., and Benton Jr., W. C. (2007). Supply chain practice and information sharing. Journal of Operations Management, 25(6), 1348-1365. 
